\title{
A novel form of PCD that impacts nodal, but not tracheal cilia
}

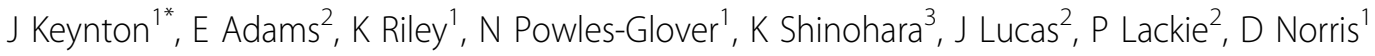 \\ From Cilia 2014 - Second International Conference \\ Paris, France. 18-21 November 2014
}

Motile cilia, in the embryonic node, drive a leftward fluid flow (termed nodal flow) that establishes the left-right axis. We identified $\operatorname{lrm} 5$ in a genetic screen for mouse leftright patterning mutants - the embryos exhibited disturbed situs. Mapping and sequencing revealed a novel mutation in the axonemal dynein heavy chain locus Dnah11: loss of function gives rise to immotile cilia in mice; many human primary ciliary dyskinesia (PCD) patients with DNAH11 mutations have hyper-motile cilia. To our surprise, unlike the previously characterised Dnah $11^{i v}$ mutant, $\operatorname{lrm} 5$ tracheal ciliary beat frequency (CBF) was normal. However, the number of $l r m 5$ homozygotes at weaning was lower than Mendelian ratios would predict. Age of death analysis identified a $50 \%$ reduction in embryos between E14.5 and E15.5, consistent with death from embryonic cardiac failure. Expression analysis of early molecular markers of left-right asymmetry revealed randomised or bilateral activation of the normally leftsided Nodal Cascade. As this suggested an early, primary patterning defect, we analysed nodal flow by particle image velocimetry (PIV); rather than the wild-type leftward flow, or the absent flow in Dnah11 ${ }^{i v}$, we observed a chaotic fluid flow in $\operatorname{lrm} 5$ nodes. We therefore assessed nodal CBF and ciliary amplitude by DIC microscopy; $l r m 5$ cilia beat at $1.5 \mathrm{x}$ normal frequency, but with an abnormal motion. In summary, lrm5 is a novel form of PCD, impacting nodal but not tracheal ciliary beating. We would predict that equivalent mutations in humans might underlie situs defects and congenital heart disease in the absence of respiratory disease.

\section{Authors' details}

'MRC Harwell, Oxford, UK. ${ }^{2}$ Southampton General Hospital, University of Southampton, Southampton, UK. ${ }^{3}$ Osaka University, Osaka, Japan.

${ }^{1}$ MRC Harwell, Oxford, UK

Full list of author information is available at the end of the article
Published: 13 July 2015

doi:10.1186/2046-2530-4-S1-015

Cite this article as: Keynton et al:: A novel form of PCD that impacts nodal, but not tracheal cilia. Cilia 2015 4(Suppl 1):015.
Submit your next manuscript to BioMed Central and take full advantage of:

- Convenient online submission

- Thorough peer review

- No space constraints or color figure charges

- Immediate publication on acceptance

- Inclusion in PubMed, CAS, Scopus and Google Scholar

- Research which is freely available for redistribution

Submit your manuscript at www.biomedcentral.com/submit
() Biomed Central
C Biomed Central

C 2015 Keynton et al. This is an Open Access article distributed under the terms of the Creative Commons Attribution License (http:// creativecommons.org/licenses/by/4.0), which permits unrestricted use, distribution, and reproduction in any medium, provided the original work is properly cited. The Creative Commons Public Domain Dedication waiver (http://creativecommons.org/publicdomain/ zero/1.0/) applies to the data made available in this article, unless otherwise stated. 